\title{
Organizational Resilience and Corporate Performance of Deposit Money Bank in Port Harcourt, Nigeria
}

\author{
A.O. Oparanma $P h D$ \\ Department of Management \\ Faculty of Management Sciences \\ Rivers State University Oroworukwo \\ PMB 5080, Port Harcourt, Nigeria \\ Elezie Patricia Ulunma \\ Department of Management \\ Faculty of Management Sciences \\ Rivers State University Oroworukwo \\ PMB 5080, Port Harcourt, Nigeria
}

\begin{abstract}
This study examined the relationship between organizational resilience and corporate performance of deposit money banks in Port Harcourt. The general purpose was to examine the effect of organizational resilience on corporate performance of deposit money banks while the specific objectives are to examine the effect of organizational learning and adaptive capabilities on corporate performance. Twenty-one deposit money banks operating in Port Harcourt. Sixty three sample representatives were selected from the deposit money. Organizational resilience measures are organizational learning and adaptive capabilities while corporate performance measures are profitability, market share and employee satisfaction. Primary data were sourced through questionnaires and administered to managers at the regional office of the deposit money banks. Descriptive statistics and Spearman rank correlation coefficient with the aid of Statistical Packages for Social Science were used as data analyses techniques. Findings reveal a correlation coefficient of 81.4 percent and probability of 0.0000 between organizational learning and corporate performance. 89.4 percent and probability of 0.0000 between adaptive capabilities and corporate performance. The finding indicates that organizational resilience has positive and significant relationship with corporate performance of the deposit money banks. It therefore recommends that techniques and strategic measures should be devise to enhance organizational resilience among the deposit money banks in Port Harcourt.
\end{abstract}

Keywords: Organizational Resilience, Corporate Performance, Deposit Money Bank, Adaptive Capability, Organizational Learning.

\section{Introduction}

In organizational theory, resilience as a term is studied in crisis management, disaster management, and high reliability organizations. Despite the growing interest in the term, there is no agreed upon and widely accepted measure of organizational resilience construct. Campbell Sills and Stein (2007) states that, in the psychology literature there is a consensus on the reliability and validity of the Conner-Davidson measure. In organizational theory literature, there are attempts to analyze the construct with different dimensions. Hind and Rowley (1996) studied the term with dimensions of change capacity, organizational commitment, social relationships and team integrity and reality perception. Mallak (I998) with the aim to dimensionalize the construct and to measure it, studies organizational resilience under six dimensions of goal directed solution seeking, avoidance, critical understanding, role dependence, source reliance, resource access and develops a scale. Somers (2009) adopts the scale developed by Mallak (I998) and proves that the scale is reliable and valid. Tierney (2003) also dimensionalizes the construct with four dimensions of robustness, redundancy, resourcefulness and rapidity.

Disasters such as the recent economic recession, macroeconomic instability and monetary policy shocks are reminders of the need for corporate organizations to engage in emergency preparedness initiatives to enhance their resilience in the event of a disaster. In particular, financial service organizations such as the banking industry that transmit the government monetary policy. To achieve this, organizations must engage in activities that promote their resilience. To achieve organizational resilience, it is important to understand what features within an organization promote resilience. Several features have been identified in the extant literature, such as leadership, communication, organizational culture, and internal resources (Crichton, Ramsay, \& Kelly, 2009; Lengnick-Hall, Beck, \&Lengnick-Hall, 20I I; Wyche, \& Pfefferbaum, 2008; Stephenson, 2010). 
The relationship between organizational resilience and corporate performance has well been documented in literature with findings inconclusive and controversial as some found positive relationship between organizational resilience and corporate performance (Lengnick, 20I I; Kantur and Iseri, 20I2; Wicker, Filo and Geskelly, 20I3) others found negative relationship and concluded that resilience measures are irrelevant in managing uncertainties in the business environment (Tierney, 2013; Teixeire and Werther, 2013; Pal, 2014). The divergences in the studies above could be traced to different business environment and corporate culture that affects the management. The relationship between organizational resilience and corporate performance among Nigerian firms is scanty in literature. Similar studies such as (Jaja and Amah, 2014, Umoh, and Amah, 2013) examined the effect of organizational resilience on corporate and corporate performance of manufacturing firms while the study of Ahiauzu, Eketu,(2015) examined product innovation and organizational resilience in public universities in south-south Nigeria. The lack of studies on the relationship between organizational resilience and corporate performance in Port Harcourt deposit money banks create a knowledge gap which this study intends to fill.

\section{Operationalized Framework}

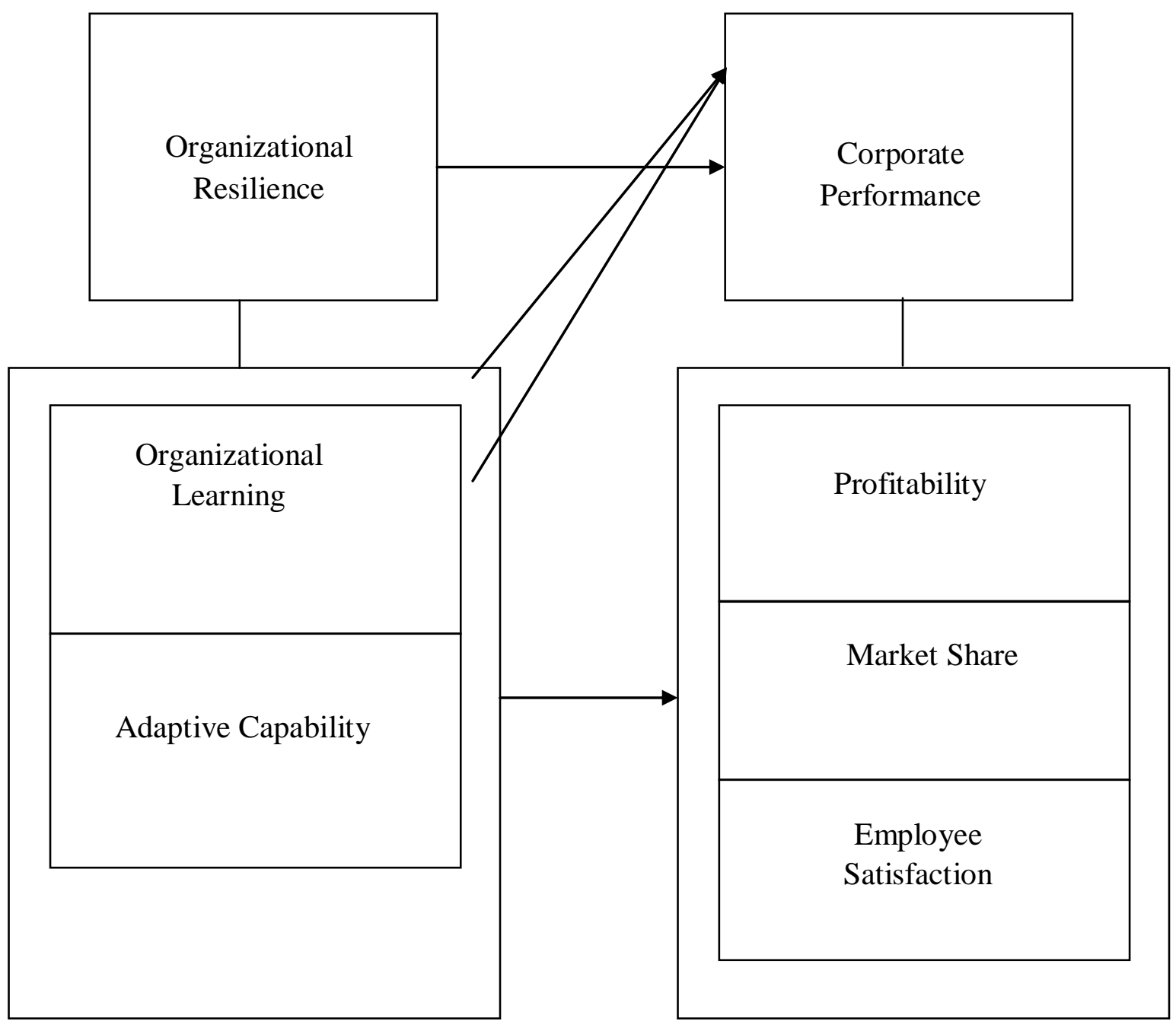

Source: Authors Operationalized Framework on the relationship between organizational resilience and corporate performance

\section{Literature Review}

2.I Theoretical Foundation

Social Learning Theory

Behaviourists emphasize the role of environment in directing behaviour. They work observing the ways in which their subjects respond to stimuli. The Behaviourist Albert Bandura's social learning theory of 1977 has become the most influential theory of 
learning and development. While rooted in the basic concepts of traditional learning theory, Bandura believed that direct reinforcement could not account for all types of learning. His theory added a social element, arguing that people can learn new information and behaviours by watching other people; known as observational learning (or modeling), this type of learning can be used to explain a wide variety of behaviours as in the case of employee learning of particular behaviours and new ways of doing things.

\section{Resource Based View}

Resource Based View (RBV) holds that firms can earn sustainable super-normal returns if and only if they have superior intangible resources that are protected by some form of isolating mechanism preventing their diffusion throughout industry. Wernerfelt (1984) \& Rumelt (1984) noted that the fundamental principle of the RBV is that the basis for a competitive advantage of a firm lies primarily in the application of the bundle of valuable resources at the firm's disposal. To transform a short-run competitive advantage into a sustained competitive advantage requires that these resources are heterogeneous in nature and not perfectly mobile (Barney, I991; Peteraf, I993).

Essentially, these valuable resources become a source of sustained competitive advantage when they are neither perfectly imitable nor substitutable without great effort (Barney, I99I). In a nutshell therefore, to achieve these sustainable above a verage returns, the firm's bundle of resources must be valuable, rare, imperfectly imitable and non-substitutable (Barney, I99I). The extent to which external and internal factors affect managerial discretion will depend on, among other factors, the manager's locus of control, perception of discretion and the amount of power that people perceive the manager to possess.

\subsection{Conceptual Framework Organizational Resilience}

Madni (2007) defined resilience as the ability to anticipate a perturbation, to resist by adapting and to recover by restoring the pre-perturbation state as much as possible. McManus et al.; (2008) asserts that the numerous concepts that emerge from definitions of organizational resilience include knowledge of the environment, level of preparation, anticipation of perturbations, adaptation, and capacity to recover. The ability of organizations to absorb shock or develop resistance in the face of perturbances within its environment is a reflection of how prepared the organization can be. Alastir (20I0) contends that managers of resilient organizations should understand at board level, the environment in which their organizations operates, and be aware of changes which may represent a risk to their people, facilities, activities, services and supply chains. He maintains that managers need to understand the increasing complex cultural, political, legal, regulatory, economic, technological, natural and competitive context within which they operate and monitor key issues and trends that may impact on the objectives of the organization and the perceptions and values of external stakeholders.

\section{Measures of Organizational Resilience}

The measures of Organizational resilience include Organizational Learning, Adaptive capacity and Dynamic Capability.

\section{Organizational Learning}

Organizational learning has been defined in the web dictionary as an Organization-wide continuous process that enhances its collective ability to accept, make sense of and respond to internal and external change. Organizational learning requires systematic integration and collective interpretation of new knowledge that leads to collective action and involves risk taking as experimentation. Organizational Learning is an area of knowledge within organizational theory that studies models and theories about the way an organization learns and adapts. In organizational development (OD) is as characteristic of an adaptive organization, an organization that is able to see changes in signals from its environment (both internal and external) and adapt accordingly. Learning is acquiring new, or modifying existing knowledge, behaviors, skill, values, or preferences and may involve synthesizing different types of information.

\section{Levels of Organizational Learning}

Organizational learning is a multilevel concept occurring at individual, group and institutional levels. The process is linked by four psychological processes of intuition, interpretation, integration and institutionalization (Crossan, Lane and White, I999). Feed forward learning focuses on proactively anticipating environmental changes through individual intuition. Intuition occurs at the individual level which is integrated into group learning and then into learning at institutional level. Feedback indicates how learning that is embedded in organizations affect individuals and groups (Crossan and Bedraw, 2003). The framework of organizational learning provides important insights by linking the three levels of individual, group and institutional learning and showing the linkage to strategic renewal. It recognizes the fact that learning is a multilevel process linked to the four psychological processes of intuition, interpretation, integration and institutionalization. Organizational learning is defined by four interrelated processes of intuition, integration, interpretation and institutionalization. Individuals are important in 
organizational learning process. However, organizational learning is not simply the sum of each members learning (Levitt and March, I988). Intuition is the basic learning process at the individual level.

\section{Adaptive Capacity}

Walker et al., (2002) define adaptive capacity as an aspect of resilience that reflects learning, flexibility to experiment and adopt novel solutions, and the development of generalized responses to broad classes of challenges. Adaptive capacity may be defined as the ability or inclination of individual or group to maintain an experimental attitude towards new situations as they occur and to act in terms of changing circumstances. Adaptive capacity is addressed in this context through two approaches; socio environmental, and organizational (McManus, 2007). An organization's ability to adapt is at the heart of their ability to display resilient characteristics. Amah and Baridam (2012) discuss the importance of adaptation and note that the aim is to create advantages over less adaptive competitors. This suggests that adaptive capacity is also linked to competitiveness. Dalziell and McManus (2004) define adaptive capacity as, the engagement and involvement of organizational staff so that they are responsible, accountable and occupied with developing the organization's resilience through their work because they understand the links between the organization's resilience and its long term success.

\section{Dynamic Capabilities}

Teece, et al. (2010) defined Dynamic capabilities as "the firm's ability to integrate, build, and reconfigure internal and external competencies to address rapidly changing environments". Dynamic capabilities can be distinguished from operational capabilities which pattern to the current operations of an organization. Dynamic capabilities, by contrast, refer to the capacity of an organization to purposely create, extend, or modify its resource base (Helfat et al, 2007) cited in Teece, et al., (2010). The basic assumption of the dynamic capability is framework is that core competencies should be used to modify short-term competitive positions that can be used to build longer-term competitive advantage. These authors affirm that the Literature on dynamic capabilities grew out of (I) the resource based view of the firm and (2) the concept of "routines" in evolutionary theories of the organization (Nelson and Winter, 1982) cited in Teece, et al (2010).It thus provides a bridge between the economic-based strategy literature and evolutionary approaches to organization. They opine that three dynamic capabilities are necessary in other to meet new challenges.

\section{Concept of Corporate Performance}

Kohli and Jaworski (I996) observed that organizational performance consists of cost based performance measures, which reflect performance after accounting for the cost of implementing a strategy (sales and market share). Aluko (2003) defined performance as the execution and accomplishment of work tasks or goals to a certain level of desired satisfaction and that organizational performance is defined in terms of the ability of an organization to satisfy the desired expectations of three main stakeholders comprising; owners, employees and customers. An institution that persistently makes will ultimately deplete its capital base, which in turn put equity and debt holders at risk. Moreover, since the ultimate purpose of any profit-seeking organization is to preserve and create wealth for its owners the bank's return on equity (ROE) needs to be greater than it costs of equity in order to create shareholder's value. Dauda (2010) highlighted organization performance is determined by the demand by its products or services. Many organizations put in place methods and strategies that could enable them attract customers and improve the quality and quantity of their product. From the foregoing definitions, it can be deduced that performance is efficient and effective use of resources by an organization for accomplishment of its objective or goal leading to increase in the following: share price, sales, market share, sustainable profitability, taking, leverage and demand of its product or service and satisfying and desired expectations of its three main stakeholders comprising owners, employees and customers.

\section{Measures of Corporate Performance}

Firm performance from an accounting literature perspective hinges on company profitability and performance of stocks in the capital market. The measures of firm performance based on literature can be broadly classified into two namely the market oriented measures and the accounting oriented measures. Furtado \& Karan, (1994) provide evidence that boards prefer accounting measures market to measures in evaluating managerial performance Accounting based measures are adopted in the study as performance measures because they provide the most available data. This section gives a brief overview of the prominent market and accounting based measures. Return on Assets Accounting performance measures (like ROA) have an advantage because they are backward looking (Jong, Gispert, Kabir, \& Renneboog, 2002).ROA gives an idea as to how efficient management is at using its assets to generate earnings (Khatab, Masood, Zaman, Saleem, \& Saeed, 20II). It is often computed by dividing Profit after tax by total assets alternatively, it can be calculated by dividing Earnings before Interest and Tax (EBIT) by total assets. This accounting based performance measure can be tagged as forward looking because profit for the period is measured against sales for the current period. Profit margin is calculated as profit after tax divided by turnover or net sales. The essence is that it provides information on the percentage of profit that sales are able to generate. 


\section{Profitability}

Profitability on the other hand is the primary goal of all business ventures. Without profitability, the business will not survive in the long run. Profitability is measured with income and expenses and normally divided into gross profit and net profit. Gross profit as a marketing metric refers to the profit generated by a firm (Pandey, 2005). It is calculated as the total sales minus the cost of those sales. The net profit is a financial metric that is equally important to the marketing manager. It is synonymous with bottom line and indicates whether, after all the expenses of the firm have been taken into consideration, the company is still making profit. The net profit margin is the marketing metric that represent the ultimate profitability of the firm expressed in percentage and it is useful in comparing one period against another or comparing one company with another.

\section{Market Share}

A company's market share is its portion of total sales in relation to the market it operates within. Market share represents the percentage of an industry or market's total sales that is earned by a particular company over a specified time period. Market share is calculated by taking the company's sales over the period and dividing it by the total sales of the industry over the same period. This metric is used to give a general idea of the size of a company in relation to its market and its competitors. Market share increases can allow a company to achieve greater scale in its operations and improve profitability.

\section{Employee Satisfaction}

Anderson (200I) defines job satisfaction as a pleasurable or positive emotional state resulting from the appraisal of one's job or job experience. Anderson (200I) notes that the definition incorporates both cognition (appraisal) and affects (emotional state) thus, Anderson assumes that job satisfaction results from interplay of cognition, and affect, or put differently; thoughts and feelings. Robbins (2005) conforms to Anderson (200I) by defining job satisfaction as a collection of feelings an individual holds towards his or her job. A person with a high level of job satisfaction holds positive feelings towards the job while a person who is dissatisfied with his or her job holds negative feelings towards it. Thus job satisfaction is a result of the overall reaction towards a job.

\section{Organizational Dynamics and Corporate Performance}

Dynamic capabilities and organizational performance have been examined mainly in terms of either the economic performance of the firm or changes in operational capabilities. However, the mechanisms through which they influence performance remain unclear. Some scholars posited a direct relationship between dynamic capabilities and performance. In accordance with this view, several empirical studies report a direct relationship between what the authors conceptualize as dynamic capabilities and performance (Garc1'a-Morales, et al., 2007; Kor \& Mahoney, 2005; Wu, 2007; Zhang, 2007). With regard to the performance indicators, there is considerable variation in what constitutes performance. Many studies focus on economic performance (Morgan, Vorhies \& Mason 2009; Wang, Klein, \& Jian 2007; Zhang, 2007), whereas others consider innovative or technology performance, environmental performance, and international performance(Ellonen, Wikstro"m, \& Jan- tunen, 2009; Chen \& Jaw, 2009; Russo, 2009)A number of studies have been carried out by various researchers on Dynamic Capabilities and the 'Performance of Organizations.

Li \& Liu (2014) examined dynamic capability, environmental dynamism and competitive advantage in 217enterprises in China. Using survey research design, they assessed the role of dynamic capability on gaining competitive advantage. Their findings revealed that dynamic capabilities have a significant positive impact on competitive advantage, and that environmental dynamism is an antecedent of dynamic capabilities and facilitates their development. Umoh et al, (20I4) examined the effect of Management Development on Organizational Resilience in the Nigerian manufacturing industry. A total of I40 employees were randomly drawn from employees of the 3 I manufacturing companies in Port Harcourt. The instruments used for data collection were questionnaire and oral interview. A total of 93 copies of the questionnaire were retrieved and analyzed. Spearman's Rank Correlation Statistical tool was used to test the hypotheses.

Umoh \& Amah (2013) examines the relationship between knowledge management and organizational resilience. The sample for the study consisted of one hundred and twenty-eight (128) employees from the thirty-four manufacturing companies that are registered with the manufacturers Association of Nigeria, Rivers State Council. The study utilized both quantitative data (questionnaire) and qualitative data (interview). The spearman rank correlation coefficient and Multiple Regression Model using the Statistical Package for Social Sciences (SPSS) version I5were utilized for the analysis of data. Our finding revealed a positive and significant relationship between knowledge management and organizational resilience. Specifically, knowledge acquisition, knowledge storage, knowledge sharing and knowledge utilization were revealed to have a positive and significant influence on organizational resilience. Based on this finding, it was concluded that knowledge management enhances organizational resilience. 
More specifically, it was concluded that knowledge acquisition, knowledge storage, knowledge sharing and knowledge utilization enhances organizational adaptation, organizational resourcefulness, and organizational learning.

\section{Organizational Learning and Corporate Performance}

Related with the literature on organizational learning in relation with firm performance; organizational learning, as the source of knowledge creation and knowledge as the unique, inimitable and infinite resource of the resource-based theory, is emphasized as the factor in the achievement of competitive advantage. The literature views organizational learning as the basis of gaining a sustainable competitive advantage and a key to firm performance (Martinez-Costa and Jimenez-Jimenez, 2009). Organizations that embrace strategies consistent with the learning organization are thought to achieve improved performance (Ellinger et al, 2002; Calantone et al., 2002). Ellinger et al. (2002) examined the relationship between organizational learning and firm's financial performance. Their research aims to determine the effects of continuous learning, inquiry and dialogue, collaboration and team learning, empowerment of people towards collective vision, connection of organization to its environment and the leadership support on the financial measures of performance (ROE, ROA, MVA). Their exploratory research suggests a positive association between learning organization practices and objective measures of firms' financial performance. Additionally, Baker and Sinkula (1999) not only think that the organizational learning orientation of a firm affects its performance directly but they also think there's an indirect relationship between.

\section{Adaptive Capability and Corporate Performance}

In the general theory, adaptive capabilities are considered to be a source of sustained competitive advantage in situations where the competitive landscape is shifting and there is rapid and unpredictable change (Teece, 2007). According to Zahra et a(2006) three elements regarding the presence of adaptive capabilities have come to be confounded in the literature: (I) the ability to solve a problem (a substantive capability), (2) the presence of rapidly changing problems (an environmental characteristic), and (3) the ability to change the way the firm solves its problems (a higher-order dynamic capability to alter capabilities). To date the adaptive capabilities literature has focused mainly on the application of adaptive capabilities to the economic goals of firms (Wu et al. 20I2).Recent studies have suggested that dynamic capabilities should be applied to the process by which firms undertake sustainable development strategies as these situations are complex and characterized by rapid and unpredictable change (Hart \& Dowell, 20II; Wu et al. 2012). Sustainability has been recognized as a dynamic concept; it is not a fixed state, but rather a process of change that is not defined by precise tangible objectives, definite criteria and unambiguous decisions (Voss et al, 2005).

\section{Research Methodology}

The design that was used for this study was survey research design. It also used descriptive research design; the researcher used survey method this is because all the entire population cannot be studied so a survey more appropriate.

\section{Population of the Study}

The target population for this study was 3 regional managers selected from the regional offices from each of the 2I deposit money banks that are in Port Harcourt: Access Bank, Diamond Bank, Ecobank, First City Monument Bank, Fidelity Bank, First Bank, Guarantee Trust Bank, Heritage Bank, Keystone Bank, Skye Bank, Stanbic IBTC, Sterling Bank, United Bank for West Africa, Union Bank, Unity Bank, Wema Bank, Zenith Bank, Jaiz Bank, Standard Chartered Bank, Main street Bank, City Bank. Therefore the population of the study comprised of sixty-three (63) managers from the regional offices of the deposit money banks.

\section{Sampling Procedure and Size Determination}

The sampling for this study constituted of regional managers of the 2I deposit money banks in Port Harcourt. The study will use the total population as a sample size.

\section{Data Collection}

The questionnaire was used as principal tool in collecting primary data. The questionnaire contained structured, semi-structured and open-ended questions. The questionnaire was structured into two sections. The first section requested the general information of the respondent; the second captured information on the research problems. The questionnaire was designed in five options, very high extent, high extent, moderate extent, very low extent and low extent.

Description of the Research

Instrument

The major research instrument that was used for this study was a structured questionnaire. The questionnaire was formulated considering the research questions and hypotheses. The designed questionnaire has two sections- A and B. All the questions in 
section $\mathrm{A}$ are drawn and aimed at providing some general information from the respondents while the remaining questions in section $\mathrm{B}$ was meant to directly address the research questions. In the design of the questionnaire, five - point likert scale format was used.

\section{Measures of Variables}

The dependent variables in this study comprise, profitability, market share and employee satisfaction. The measurement of the variables was adopted from the study of Amir and Amen, 2013, Peter, 2014 and Claoudo \& Ane 20I4. 5 items are used to measure each of the dimensions of the corporate performance. The dependent variables are measured by five items. The respondent views are scaled in a 5 -point scale (very high extent) $=5$ points, high extent $=4$ points, moderate extent $=3$ points, very low extent $=2$ points and low extent $=$ I point. This was done to measure respondent views on organizational resilience and corporate performance of Deposit Money Banks.

The measurement for the independent variables was adopted from the study (Beattie \& Griffin 20I4). It comprises organizational learning and adaptive capacity. The independent variables are measured by five items A 5-point scale (very high extent $)=5$ points, high extent $=4$ points, moderate extent $=3$ points, very low extent $=2$ points and low extent $=$ I point.

\section{Data Analysis Technique}

The statistical techniques employed in analyzing data collected in this study are: Tables effectively order and summarize the quantitative data. They are used to arrange facts and figures in columns and rows. These facts and figures can be systematically examined (Ojo, 2005). These are used in translating frequency counts into percentage. These percentages were used to show the distribution of respondents according to their responses (Ojo, 2005). It is used as a measure of the strength of linear dependence between two variables. According to Ojo (2005) correlation is used to find out if there is any relationship between two variables. While doing this, a variable is correlation to another variable. The correlation coefficient ranges from $-I$ to I. A value of I implies that a linear equation describes the relationship between $\mathrm{X}$ and $\mathrm{Y}$ perfectly, with all factors affecting $\mathrm{Y}$ held constant for which $\mathrm{Y}$ increases as $\mathrm{X}$ increases. A value of $-\mathrm{I}$ implies $\mathrm{Y}$ decreases as $\mathrm{X}$ increases. A value of 0 implies that there is no linear correlation between the variables.

\section{Validity Test}

Validity refers to the degree to which evidence and theory support the interpretation of test scores entailed by use of tests. According to Mugenda and Mugenda (I999), validity is the accuracy and meaningfulness of inferences, which are based on the research results. It is the degree to which results obtained from the analysis of the data actually represent the variables of the study. For validation to be achieved, the study conducted a pilot testing. The validation of the questionnaire was carried out through the following ways: the researcher was request research experts, professionals of education and administration to review the items on the instrument to determine whether the set of items accurately represent the variables under study. They were asked to read, judge, make recommendations and gave feed back to the researcher.

\section{Reliability Test}

According to Mugenda \& Mugenda (I999), reliability is the ability of a research instrument to consistently measure characteristics of interest over time. It is the degree to which a research instrument yields consistent results or data after repeated trials (Nachmias, 1996). If a researcher administers a test to a subject twice and gets the same score on the second administration as the first test, then there is reliability of the instrument. The error may arise at the time of data collection and may be due to inaccuracy by the researcher or inaccuracy by the instrument. To establish the reliability of the research instruments, the researcher carried out a pilot test of the instruments using another similar group with the same characteristics as the one targeted in the study. The reliability of the structured questionnaires was computed using split half method with the help of Statistical Package for Social Science (SPSS). If the value found falls within the accepted levels (0.05), the structured questionnaires were held reliable (George \& Mallery, 2003).

\section{Analysis and Discussion of Findings}

The source of data used in the study was questionnaire which was administered to regional office of the twenty one (2I) deposit money banks Port Harcourt. Out of sixty three (63) questionnaires administered, fifty seven (57) were retrieved which represents $90.4 \%$ while six (6) questionnaires which represent $9.6 \%$ were not retrieved. Out of the fifty seven questionnaire (57) retrieved, three (3) was rejected which represents $4.8 \%$ of the total questionnaire administered. The table below gives the details. 
Table I Analyses of questionnaire according to rank in the bank

\begin{tabular}{llll}
\hline S/No & Rank & $\begin{array}{l}\text { Questionnaire } \\
\text { Administered }\end{array}$ & \% Distribution \\
\hline I. & Top Level Managers & 6 & I I.I \\
\hline 2. & Middle Level Managers & I8 & 33.3 \\
\hline 3. & Low Level Managers & 30 & 55.6 \\
\hline & Total & 54 & 100.0 \\
\hline
\end{tabular}

Source: Field survey (2018)

Table 2: Analysis of Respondents by Management Level

\begin{tabular}{llll}
\hline I. & Top Level Managers & 6 & II.I \\
\hline 2. & Middle Level Managers & I8 & 33.3 \\
\hline 3. & Low Level Managers & 30 & 55.6 \\
\hline & Total & 54 & 100.0 \\
\hline
\end{tabular}

From table 4.3 above, out of the fifty four (54) questionnaires administered, six (6) questionnaire was administered to the Top Level Managers in the 2I deposit money banks in Port Harcourt which represents II.I percent, I8 respondents are middle level managers which represent 33.3 percent of the total questionnaire distributed while 30 respondents are lower level managers, this is 55.6 percent of total questionnaire distributed to the managers of the 2I deposit money banks in Port Harcourt at their regional offices.

Table 3: Analyses of questionnaire according to Time Duration in the Bank

\begin{tabular}{llll}
\hline S/No & Time Duration & Questionnaire Retrieved & \% Distribution \\
\hline $\mathrm{I}$ & O - I0 years & 2 & 3.7 \\
\hline 2 & I I - 20 years & 23 & 42.6 \\
\hline 3. & 2I -30 years & $2 \mathrm{I}$ & 38.9 \\
\hline 4. & 3I and above & 8 & $\mathrm{I} 4.8$ \\
\hline & Total & 54 & I00
\end{tabular}

Table 4.4 above reveal questionnaire retrieved according to the time duration of staff in the commercial banks, the table proved that 2 respondents are between the time $0-10$ years which represents 3.7 percent, 23 respondents are between the time II - 20 years which represents 42.6 percent, 2I respondents are between the time 2I - 30 years which represents 38.9 percent and 8 respondents are between the time $3 \mathrm{I}$ and above years which represents $\mathrm{I} 4.8$ percent.

Table 4: Analyses of questionnaire according to Gender

\begin{tabular}{llll}
\hline S/No & Gender & Questionnaire Retrieved & \% Distribution \\
\hline $\mathrm{I}$ & Male & 34 & $28 . \mathrm{I}$ \\
\hline 2 & Female & 20 & $52 . \mathrm{I}$ \\
\hline & Total & 54 & $\mathbf{8 0 . 2}$ \\
\hline
\end{tabular}

Table 4.6 above indicates respondents according to gender, 34 respondents that represents $28.1 \%$ are male while 20 respondents that represent $52.1 \%$ are female.

Table 5: Organizational Learning and Corporate Performance of Deposit Money Banks

\begin{tabular}{llllll}
\hline & & Frequency & Percent & Valid Percent & Cumulative Percent \\
\hline Valid & Very High & 33 & $6 \mathrm{I.I}$ & $6 \mathrm{I.I}$ & $6 \mathrm{I.I}$ \\
\hline High & $\mathrm{I} 9$ & 35.2 & 35.2 & 96.3 & I00 \\
\hline Moderate & 2 & 3.7 & 3.7 & 0 \\
\hline
\end{tabular}




\begin{tabular}{cllll}
\hline Low & 0 & 0.0 & 0.0 & 100.0 \\
\hline Total & 54 & 100.0 & 100.0 & \\
\hline
\end{tabular}

The table above examined the extent to which organizational learning affects corporate performance of deposit money banks in Port Harcourt. Respondents from the table proved that 33 (61.1\%) out of the 54 respondents agree that organizational learning affects performance of the deposit money banks to a very high extent, 19 (35.2\%) respondents accepted that organizational learning affects corporate performance of deposit money banks to a high extent, $2(3.7 \%)$ respondents opined that organizational resilience affects corporate performance of deposit money banks in Port Harcourt to a moderate extent. None of the respondents agreed on very low extent and low extent, from the above, we can inductively agree that organizational resilience affects the performance of the deposit money banks in Port Harcourt to a very high extent.

Table 6: Adaptive Capability and Corporate Performance of Deposit Money Banks

\begin{tabular}{llllll}
\hline & & Frequency & Percent & Valid Percent & Cumulative Percent \\
\hline Valid & Very High & 27 & 50.0 & 50.0 & 50.0 \\
\hline High & I7 & 31.3 & 31.3 & 81.3 \\
\hline Moderate & 5 & 9.3 & 9.3 & 90.6 \\
\hline Very Low & 3 & 5.6 & 5.6 & 96.2 \\
\hline Low & 2 & 3.7 & 3.7 & 100.0 \\
\hline Total & 54 & I00.0 & 100.0 & \\
\hline
\end{tabular}

The table above examined the extent to which adaptive capability affects corporate performance of deposit money banks in Port Harcourt. Respondents from the table proved that 27 (50.0\%) out of the 54 respondents agree that adaptive capability affects performance of the deposit money banks to a very high extent, 17 (31.3\%) respondents accepted that adaptive capability affects corporate performance of deposit money banks to a high extent, $5(9.3 \%)$ respondents opined that adaptive capability affects corporate performance of deposit money banks in Port Harcourt to a moderate extent. $3(5.6 \%)$ respondents opined that adaptive capability affects corporate performance of deposit money banks in Port Harcourt to a moderate extent. $2(3.7 \%)$ respondents opined that adaptive capability affects corporate performance of deposit money banks in Port Harcourt to a moderate extent. From the above, we can inductively agree that organizational resilience affects the performance of the deposit money banks in Port Harcourt to a very high extent.

\section{Bivariate Analysis of the Items}

The univariate section is concerned with the presentation of the data for the variables of the study. The data presented here in is continuous and so is assessed using the mean and standard deviation in the assessment of its central tendencies and dispersion. Given the positive statements adopted in the measurement of each variable and the scaling method which ranks from $\mathrm{I}=$ for very low extent to $5=$ very high extent, a mean score of $\mathrm{x}>2.5$ with a relative standard deviation of $\mathrm{s}<2.0$ is adopted as substantial evidence of support or agreement to the indicator.

\section{Analysis of all Items on Profitability}

All the items entered in relationship to organizational resilience and profitability reveal a mean greater than 2.5 and a standard deviation less than the critical value of 2.5 , we accept that the respondents strongly agree that organizational resilience affects profitability of deposit money banks in Port Harcourt.

\section{Analysis of all Items on Market Share}

All the items entered in relationship to organizational resilience and market share reveal a mean greater than 2.5 and a standard deviation less than the critical value of 2.5 , we accept that the respondents strongly agree that organizational resilience affects market share of deposit money banks in Port Harcourt.

\section{Analysis of all Items on Employee Satisfaction}

All the items entered in relationship to organizational resilience and employee satisfaction reveal a mean greater than 2.5 and a standard deviation less than the critical value of 2.5 , we accept that the respondents strongly agree that organizational resilience affects market share of deposit money banks in Port Harcourt. 


\section{Analysis of all Items on Organizational Learning}

The result of analysis on organizational learning shows that respondents in the selected deposit money banks affirm to their bank practices and adoption of activities which can be referred to as entailing organizational learning; this is as the mean scores for the dimensions of all the items and organizational learning as well as their corresponding indicators, are all revealed to have mean scores and standard deviations which indicates the significance of organizational learning as a practice within the deposit money banks.

\section{Analysis of all Items on Adaptive Capabilities}

The result of analysis on adaptive capability shows that respondents in the selected deposit money banks affirm to their bank practices and adoption of activities which can be referred to as entailing adaptive capabilities; this is as the mean scores for the dimensions of all the items and adaptive capabilities as well as their corresponding indicators, are all revealed to have mean scores and standard deviations which indicates the significance of adaptive capabilities as a practice within the deposit money banks.

\section{Discussion of Findings}

Deposit money banks operate in four different environments that have direct effect on the operational efficiency and profitability of the industry; these are the internal environment, the monetary policy environment, the macroeconomic environment and the international environment. Policy changes from this environment have direct impact on the performance of the industry. For instance, the global financial crises min 2007/2008 affected the performance of the industry and the Nigerian macroeconomic instability in the past 2 years has great impact on the performance of the industry. The objective of this study was to investigate the effect of organizational resilience on the performance of deposit money banks in Port Harcourt.

From hypothesis one in relation to research question one, the study found a correlation coefficient of .8I4(8I.4\%) which means strong and positive relationship between organizational learning and corporate performance of the 2I deposit money banks in Port Harcourt. The findings implies that resilience measures such as organizational learning can be used as hedging against unforeseen circumstances and environmental challenges that have the capacity of affecting negatively the performance of deposit money banks in Port Harcourt. This finding confirms the expectation of the results and validates various measures put in place by the management of deposit money banks to enhance organizational resilience such as employee training, organizational learning and other measures. The findings confirm the empirical findings of Arend (20I4) that there is positive and significant relationship between dynamic capabilities and financial performance of SMEs in America and the findings of Marcus and Anderson (2006) on the significant relationship between dynamic capabilities and business competencies in United States of America.

This finding confirm the findings of Umoh et al., (2013) on the effect of knowledge creation on the absorptive capacity of selected manufacturing firms, it is also in line with the findings of Umoh and Amah (20I4) on the relationship between knowledge management and organizational resilience.

Research question two and hypothesis two investigated the extent to which adaptive capabilities affects corporate performance deposit money banks in Port Harcourt. Empirical findings from the study indicate that there is positive and significant relationship between adaptive capabilities of the deposit money banks and performance. The positive correlation coefficient of $.894(89.4 \%)$ proved that adaptive capabilities enhances performance of the deposit money banks to a great extent. This enables us to accept the alternate hypothesis against the null hypothesis. This finding confirms our a-priori expectation and also justifies reasons for corporate resilience measures in the banking industry. The findings of this study is in line with the findings of Ellinger et al., (2002) on positive association between learning organization practices and objectives measures of firms financial performance, the findings of Baker and Sinkula (1999) that the organizational learning orientation of firm affects its performance, the findings of Calantone et al., (2002) that organization learning affects organizational performance through firms innovative performance.

\section{Conclusion}

The objective of this study was to investigate the relationship between organizational resilience and corporate performance of deposit money banks in Port Harcourt. The study had 2I deposit money banks operating in Port Harcourt with a sample size of sixty-three (63) representatives. Questionnaire was administered to Top Level Managers, Middle Level Managers and Low Level Managers of the deposit money banks at their regional offices. The resilience measures used in the study are organizational learning and adaptive capabilities while knowledge management measures are profitability, market share and employee satisfaction.

The study found that the correlation coefficient of $81.4 \%$ between organizational learning and corporate performance of deposit money banks and $89.4 \%$ between adaptive capabilities and corporate performance of deposit money banks. From the findings, the study concludes that organizational resilience have positive and significant relationship with corporate performance of deposit money banks in Port Harcourt. 


\section{Recommendation}

From the findings of this study, the researcher makes the following recommendations:

- The positive and significant relationship between organizational learning and corporate performance of the deposit money banks in Port Harcourt confirm the expectation of the study. Therefore, the study recommends that organizational learning should be encouraged among employees and management policy framework should be directed towards creating organizational learning environment for employees

- Work methods and procedures should be device to enhance organizational learning among staff of the deposit money banks at all level of management to achieve organizational resilience.

- Adaptive capabilities should be integrated into organizational work process, corporate mission and objective and management should effectively manage the work environment to encourage effective and efficient resilience measures that will hedge against unforeseen circumstances for the deposit money banks.

- Effective and efficient ways of applying adaptive capabilities should be device and there should be proper application of resilience in every aspect of the banking business to enhance corporate performance.

- The deposit money banks and other corporate organizations should adopt organizational cultures that enhance the effective moderation between management and organizational resilience.

- Corporate organizations such as the deposit money banks should strengthen their resilience strategies such as effective adaptive capabilities, organizational learning and absorptive capacity.

- There is need for the establish resilience management department in the deposit money bank for effective environmental scanning that will enhance resilience measures.

- Policies should be device to invite specialist for training and induction of employees of the deposit money banks for effective application of organizational learning and adaptive capabilities.

\section{Contribution to Knowledge}

This study was carried out to investigate the impact of organizational resilience on corporate performance of deposit money banks in Port Harcourt. Unlike other studies that examined organizational resilience and corporate performance of other sectors of the economy such as the manufacturing firms, this study contributes to knowledge by looking at the relationship between organizational resilience and corporate performance of deposit money banks in Port Harcourt. Therefore, the recommendation in this study will serve as a mechanism to managing the uncertainties that is encountered by corporate organization in proces s of carrying out business activities.

\section{References}

Chen, C., \& Jaw, Y. (2009). Building global dynamic capabilities through innovation: A case study of Taiwan's cultural organizations. Journal of engineering \& technology management, 26(4), 247-263.

Ellinger, A.D, (2002). The Relationship Between the Learning Organization Concept and Firms' Financial Performance: An Empirical Assessment (and Invited Reaction), Human Resource Development Quarterly, I3(I),5-29.

Helfat, C.E, (2007). The dynamic resource-based view: capability lifecycle. Clubs Impacted by Natural Disasters. Journal of Sports Management, 27, 510-525.

Kantur, D. and İşeri, S, (2012).Organizational Resilience: Conceptual Integrative Framework.Journal of Management and Organization, I8, (6), $762-773$.

Lengnick-Hall, C. A, (20I I).Beyond bouncing back: the concept of organizational resilience”. Presented at the Academy of Management Organization and Management Theory Division Seattle, Washington August I-6.

Lengnick-Hall, C.A., Beck, T.E. and Lengnick-Hall, M.L. (20I I).Developing a capacity for organizational resilience through strategic human resources management. Human Resource Management Review, 2 I, 243-255.

Li, D.-y., \& Liu, J. (20I4). Dynamic capabilities, environmental dynamism, and competitive advantage.Applied Sciences, Engineering, And Technology 6 (23), I82-205.

Marcus, A. A., \& Anderson, M. H. (2006). A general dynamic capability: Does it propagate business and social competencies in the retail food industry? Journal of Management Studies 43(I), I9-46.

Morgan, N. A., Vorhies, D. W., \& Mason, C. H. (2009). Market orientation, marketing capabilities, and firm performance. Strategic management journal, 30(8), 909-920.

Pal, R., (20I4). Antecedents of organizational resilience in economic crises-an empirical study of Swedish textile and clothing SMEs. Int. J. Production Economics, I47, 410-428.

Teece, D.J. (2010). Explicating dynamic capabilities: the nature and micro foundations of sustainable enterprise performance. Strategic Management Journal 28(13), 1319-1350.

Teixeira, E.O. and Werther Jr., W.B. (2013).Resilience: Continuous renewal of competitive advantages.Business Horizons, 56, 333-342. 
Tierney, K. (2003).Conceptualizing and measuring organizational and community resilience: lessons from the emergency response following the September I I, 200I attack on the World Trade Center. Paper presented at the Third

Umoh, G., \& Amah, E., (2013). Knowledge management and organizational resilience in Nigerian manufacturing organizations. Journal of Developing Country Studies, 3(9), I04-I20.

Umoh,G. I, (2013). Management development and organizational resilience. A Case study of some selected manufacturing firms in Rivers State Nigeria. IOSR Joumal of Business and Management, I6(2),07-I6.

Voss, J.P, (2005). Reflexive governance: a view on the emerging path. In Voss, J.P., Bauknecht, D. \& Kemp, R. (eds.) Reflexive Governance for Sustainable Development. Edward Elgar: Cheltenham. 38(4), 628-652.

Wang, E., Klein, G., \& Jiang, J. J. (2007). IT support in manufacturing firms for a knowledge.Strategic Management Journal, 24, (10), 997-1010.

Wicker, P., Filo, K. and Cuskelly, G. (2013).Organizational Resilience of Community sports

Wu, L.-Y. (2012). Applicability of the resource-based and dynamic capability views under environmental volatility. Journal of Business Research, 63(I), 27-3I.

Zahra, S.A, (2006). Entrepreneurship and dynamic capabilities: a review, model and research agenda. Journal of Management Studies 43(4),9I7-955.

Zhang, M. J. (2007). Is support for top managers' dynamic capabilities, environmental dynamism, and firm performance: An empirical investigation. Journal Of Business and Management, I3(I), 57-77

\section{Copyrights}

Copyright for this article is retained by the author(s), with first publication rights granted to the journal. This is an open-access article distributed under the terms and conditions of the Creative Commons Attribution license (http://creativecommons.org/licenses/by/4.0/). 